\title{
A Geriatria como especialidade
}

\author{
Paulo Camiz de Fonseca Filho
}

Qual a diferença entre a clínica geral e a geriatria? O geriatra só cuida de idosos? Com que idade deve-se procurar um geriatra? Essas perguntas e outras relacionadas são frequentemente direcionadas as pessoas da área de saúde e, em especial, aos médicos. Curiosamente, nem todos os médicos estão preparados para respondê-las e, não é surpreendente, não há exatamente uma resposta objetiva para essas perguntas.

Quando optei pela geriatria eu ainda era um estudante de medicina que, filho e neto mais velho de uma família de longevos, ainda tinha meus quatro avós. Mais do que isso, eu era o único membro da família que estava atuando na área de saúde. Não sabia nada de medicina mas, como muitos estudantes, sabia quem procurar. E quando algum membro da minha família passava mal ou tinha alguma intercorrência com a saúde, eu era acionado e era eu que os levava ao médico.

Depois de como acompanhante dos meus avós em consultas, passar por diversos especialistas, ainda sentia que eles, apesar dos muitos médicos, não estavam se sentindo cuidados. Quando eles apresentavam algum sintoma, nem mesmo eu sabia qual dos especialistas contactar. Conversando com colegas, fui orientado a procurar um médico que os enxergasse como um todo. Alguém que estivesse apto a cuidar da maior parte dos seus problemas e que pudesse centralizar os cuidados. Cheguei sem saber, e naturalmente, ao conceito de geriatria.

Daquele momento em diante, fui tomando contato com a especialidade pela qual me apaixonei. Inicialmente como acompanhante e, posteriormente, conforme fui avançando nos meus conhecimentos de medicina, como médico clínico geral e por fim, como médico clínico geral e geriatra. A geriatria, deve ser vista nesse sentido, como uma especialidade médica em relação a clínica geral. Assim como o são a endocrinologia, a pneumologia, a cardiologia e todas as áreas clínicas e, sendo assim, um geriatra não deixa de ser um clínico geral e não deixa de ser apto a cuidar de jovens.

Entretanto, assim como no caso da pediatria, a geriatria é repleta de particularidades que, se não levadas em consideração, podem levar a prejuízos no cuidado a essa população de doentes.

É sabido que os idosos têm passado e que, ao contrário do que se pensa, eles não voltam a ser crianças. Eles têm uma reserva funcionam menor e as conseqüências de um evento desfavorável podem ser catastróficas. Esse é considerado um dos gigantes da geriatria, as iatrogenias.

Durante o período da residência de geriatria, iniciei por acaso a minha prática médica privada. $\mathrm{Na}$ ocasião, coloco minha iniciação como sendo causada por uma mistura de síndromes geriátricas. Fui chamado para ver num atendimento domiciliar, a avó de um colega. Ela tinha problemas de memória (diagnostiquei uma síndrome demencial), dificuldade para se movimentar (diagnostiquei na mesma ocasião uma síndrome parkinsoniana) e encontravase praticamente restrita ao leito, sendo incapaz de realizar os autocuidados, caracterizando na época uma síndrome da imobilidade. Lembro-me ainda, que ela era acompanhada por um "médico" especialista em medicina ortomolecular, que a medicava com 
medicações para controlar a agitação cujo efeito colateral era parkinsonismo, além de uma série de "fórmulas próprias", cuja composição hoje me faltam a memória. Sendo assim, diagnostiquei mais uma síndrome geriátrica, a da iatrogenia. Nessa ocasião, fiquei pensando que se eu não tivesse a minha formação com geriatria e fosse apenas um clínico geral não saberia nem por onde começar.

$O$ fato é que isso faz cerca de cinco anos e, essa senhora que na ocasião tinha 90 anos, hoje irá completar 95, voltou a conversar e a reconhecer os familiares e surpreendeu a todos (inclusive a mim) quando depois de alguns meses, voltou a andar(!!!). Ela melhorou tanto que, depois de algum tempo eu já era chamado para cuidar, ainda em ambiente domiciliar, de familiares e amigos desta paciente. Os filhos dela, que também são idosos, se tornaram meus pacientes e anos depois, os seus netos (que tem entre 20 e 30 anos) também vêm se consultar comigo em meu consultório onde também exerço a clínica geral.
Com o passar dos meses, alguns pacientes só eram vistos em domicílio porque eu não dispunha de um consultório para atendê-los e foi quando eu criei coragem para alugar um local e montar o consultório. De lá para cá, as coisas só tem melhorado. O que eu posso dizer em relação a minha especialidade. Como todo o respeito às demais áreas, a geriatria na minha humilde opinião é uma das mais difíceis. Para mim, isso é uma grande motivação. Principalmente, porque sou apaixonado pelo que faço e, exercendo a geriatria, frequentemente me deparo com pacientes extremamente complexos, que me motivam a estudar e a ser um profissional e um ser humano cada vez melhor. Nunca parei de aprender e a cada dia me sinto mais estimulado a isso.

Para alguém que pensa em seguir essa área, tenho algo a dizer além de tudo o que foi dito. Idosos podem melhorar! E melhoram! Temos que saber a forma correta de atuar, de utilizar fármacos $e$ como tudo interage com os diversos sistemas num organismo com baixa reserva funcional. 